\title{
Proteolytic and Milk Clotting Activity of Fractionated Protein of Lagenaria siceraria
}

\author{
Priyanka Dash, Laxmidhar Maharana, Goutam Ghosh* \\ Department of Pharmacognosy, School of Pharmaceutical Sciences, SOA university, Bhubaneswar, India.
}

\begin{tabular}{|c|c|}
\hline ARTICLE INFO & ABSTRACT \\
\hline Article history: & \multirow{7}{*}{$\begin{array}{l}\text { The study was undertaken to evaluate milk clotting and proteolytic activity of protein fractions of seeds of } \\
\text { Lagenaria siceraria. Protein fractions were isolated by the method of differential solubility, and their protein } \\
\text { contents were estimated using Bio-Rad protein assay reagent and bovine serum albumin. The effects of } \mathrm{pH} \text { and } \\
\text { temperature on the milk-clotting and proteolytic activity were also evaluated. The isolated protein fractions } \\
\text { showed highest milk clotting activity over a broad temperature range of } 30-80{ }^{\circ} \mathrm{C} \text { and } \mathrm{pH} \text { range of } 3-9 \text {. Based } \\
\text { upon the observations, milk clotting enzymes present in different fraction of proteins of Lagenaria siceraria are } \\
\text { promising candidates for application in industrial scale for production of cheese and might be a potential } \\
\text { substitute for commercial animal rennet. }\end{array}$} \\
\hline Received on: 14/10/2015 & \\
\hline Revised on: 04/11/2015 & \\
\hline Accepted on: 15/11/2015 & \\
\hline Available online: $27 / 12 / 2015$ & \\
\hline Key words: & \\
\hline $\begin{array}{l}\text { Proteolytic, milk clotting, } \\
\text { Lagenaria siceraria }\end{array}$ & \\
\hline
\end{tabular}

\section{INTRODUCTION}

Since a long time, the conventional milk clotting enzyme, calf rennet has been derived from the stomach of suckling calves and being used as coagulant for manufacturing of cheese worldwide. As the supply of calf rennet is going to be reduced by the manufacturers, the production of cheese is now under consideration for research in milk clotting enzymes from the alternative source. The alternative sources such as various animals, plants and microbial proteases have now been considered as milk coagulants (Shieh et al., 2009). Due to high cost of calf rennet and its ethical and religious consideration associated with animals, prompted researchers to study on milk coagulants from natural sources. The milk coagulants from the plant source is of great interest since they are natural enzymes and can also be used for producing cheeses for lacto-vegetarian consumers (Bruno et al., 2010 ). Proteolytic enzymes from plant sources play important role in production of cheese, protein hydrolyzates, and tenderization of meat and preparation of medicine for digestive and anti-inflammatory disorders (Huang et al., 2011). There are so many rennet substitutes obtained from the plants such as fruits (e.g. Actinidia chinensis and Cucumis melo), latex (e.g., Ficus carica and Calotropis procera), flowers

* Corresponding Author

Goutam Ghosh, Department of Pharmacognosy, School of

Pharmaceutical Sciences, SOA university, Bhubaneswar, India

mail id:goutamghoshsps@gmail.com (e.g., Cynara cardunculus and Centaurea calcitrapa), seeds (e.g., Albizia lebbeck and Solanum dubium), leaves (e.g., Lactuca sativa) and roots (e.g., Zingiber officinale have been investigated to meet the demand of conventional calf rennet (Gagaoua et al.,2015). Lagenaria siceraria ( $L$ siceraria) belonging to family Cucurbitaceae is known as bottle gourd and used throughout the India as common vegetable. Over a long time, it is used for treatment of various disorders such as immunosuppressant, diuretic, cardio-tonic, cardio-protective and nutritive agent. The fruits are also reported to have antihepatotoxic, antioxidant, hypolipidemic and triton-induced hyperlipidemic activities in rats. The fruit contains vitamin-B complex, choline, vitamin-C, $\beta$ carotene, Cucurbitacins, fibres and polyphenol. It also contains two sterols namely campestero and sitosterol. Similarly the methanol extract was found to have flavones-C-glycosides. A ribosome inactivating protein (RIP), Lagenin isolated from the seeds of. $L$ siceraria was clamied by Kumar etal for immunoprotective, antitumor, anti HIV and antiproliferative properties (Kumar et al., 2012).

The fruits of L. siceraria was previously claim to have various amino acids such as leucines 0.8 ; phenylalanine 0.9 ; valine 0.3 ; tyrosine 0.4 ; alanine 0.5 ; threonine 0.2 ; glutamic acid 0.3 ; serine 0.6 ; aspartic acid 1.9; cystine 0.6; cysteine 0.3 ; arginine 0.4 ; and proline $0.3 \mathrm{mg} / \mathrm{g}$ (kubde et al., 2010). Studies on the vegetable proteins from the plant source is coming now in the lime light of research and more attention is paid due to increasing demand of cheap and affordable dietary protein . 
There is a growing interest in the utilization of plant proteins for the formulation of new food products. Seed flours also have appreciable functional properties that are suitable for innovative application in the food industry (Ogundele et al., 2013). This leads to research on $L$. siceraria as the seeds are alternative source of dietary protein.

The seeds are edible and used in the preparation of local soups, fermented food product (ogiri), fried cake (robo) and pudding (igbalo or ugbaotiri) (Ogunbusola et al., 2010). In view of the immense importance of the plant in the field of food industry it was thought worthwhile to investigate the proteolytic and milk clotting activity of fractionated protein of $L$. siceraria.

\section{MATERIAL \& METHODS}

\section{Isolation of protein}

L. siceraria seed kernels are separated and dried at $50{ }^{\circ} \mathrm{C}$. Then kernels were powdered using grinder and then subjected for de-fatting using $\mathrm{n}$-hexane. Then the residue $(10 \mathrm{mg})$ was mixed with $1 \mathrm{ml}$ of distilled water at $4{ }^{\circ} \mathrm{C}$ for $1 \mathrm{~h}$ and centrifuged at $10000 \mathrm{~g}$ for $20 \mathrm{~min}$. The supernatant containing albumins $\left(\mathrm{L}_{\mathrm{alb}}\right)$ was collected, while the sediment was used for further extractions. It was rinsed with $2 \mathrm{ml}$ of distilled water before homogenization, followed by centrifugation in the same condition as in the previous step to remove albumins $\left(\mathrm{L}_{\mathrm{alb}}\right)$ completely. The residual pellet obtained passed through the similar series of steps using a mixture of Tris $\mathrm{HCl} 100 \mathrm{mmol}$ in $0.5 \mathrm{NaCl}$ at $\mathrm{pH} 8.1$ to extract globulins $\left(\mathrm{L}_{\mathrm{glo}}\right)$.

The pellet was then treated with $55 \%$ isopropyl alcohol to separate prolamin $\left(\mathrm{L}_{\mathrm{pro}}\right)$ and glutelin $\left(\mathrm{L}_{\mathrm{glu}}\right)$ was separated by using $0.2 \mathrm{~N}$ acetic acid. Protein fractions were purified using acetone. The four protein fractions obtained were lyophilized and stored at $-20^{\circ} \mathrm{C}$ until further study (Teugwa et al., 2013).

\section{Determination of protein content and protein pattern analysis}

The protein content was determined using a Bio-Rad protein assay reagent (Bio-Rad, USA) and bovine serum albumin (BSA) as described by Bradford (Bradford, 1976). Absorbance was measured at $595 \mathrm{~nm}$ after the mixture was allowed to stand for $5 \mathrm{~min}$ at room temperature.

\section{Proteolytic activity}

The proteolytic activity was determined at $\mathrm{pH} 6$ using casein hydrolysis method described previously by Shieh et al (Shieh et al., 2009). The $5 \mathrm{ml}$ of $1.2 \%$ of casein solution in 0.05 mol phosphate buffer ( $\mathrm{pH}$ 6) was added to $1 \mathrm{ml}$ of sample solution and incubated at $35{ }^{\circ} \mathrm{C}$ for $10 \mathrm{~min}$. After incubation, $5 \mathrm{ml}(0.44$ $\mathrm{mol}$ ) of tri-chloroacetic acid (TCA) was added to the mixture and filtered. $1 \mathrm{ml}$ of the filtrate was then added to $2.5 \mathrm{ml}$ of $\mathrm{NaOH}$ $(0.28 \mathrm{~N})$ solution and $1 \mathrm{ml}$ phenol reagent. The optical density (OD) of the mixture was measured at $660 \mathrm{~nm}$ after incubation at $35{ }^{\circ} \mathrm{C}$ for $15 \mathrm{~min}$. All the observations are carried out in triplicate.
Proteolytic activity $=$ tyrosine equivalents released $(\mu \mathrm{g}) \times 11=1$ $\times 10 \times 2$

Where,

$11=$ total volume $(\mathrm{ml})$ of assay

$10=$ time of assay (min) as per unit definition

$1=$ volume of enzyme $(\mathrm{ml})$ of enzyme used

$2=$ volume $(\mathrm{ml})$ used in colorimetric determination

\section{Milk clotting activity}

The milk clotting activity of $L$. siceraria protein fraction was determined according to the method of Corrons et al. (Corrons et al., 2012). The substrate containing $10 \%$ skimmed milk in 0.01 mol $\mathrm{CaCl}_{2}$ and its $\mathrm{pH}$ was adjusted to 6.5 . The substrate $(2.0 \mathrm{ml})$ was pre incubated at $37{ }^{\circ} \mathrm{C}$ for $5 \mathrm{~min}$ and then $0.2 \mathrm{ml}$ of test sample was added.

The formation of curd was observed at $37{ }^{\circ} \mathrm{C}$ while test tube was rotated manually in different time intervals. The end point was recorded when discrete particles were fully separated. One milk clotting unit is defined as the amount of enzyme that clots $10 \mathrm{ml}$ of the substrate within $40 \mathrm{~min}$. All the observations are carried out in triplicate.

$\operatorname{MCA}(\mathrm{U} / \mathrm{ml})=2400 /$ clotting time $(\mathrm{s}) /$ dilution factor

\section{Effect of heating and $\mathrm{pH}$ on proteolytic and milk clotting activity}

Proteolytic and milk clotting activities were determined at $30,40,50,60,70,80$ and $90{ }^{\circ} \mathrm{C}$. To determine the effect of $\mathrm{pH}$ on the enzyme activities, protein was previously incubated in $50 \mathrm{mmol}$ citrate- sodium phosphate buffer ( $\mathrm{pH} 3.0$ to 6.0, $\left.24 \mathrm{~h}, 37{ }^{\circ} \mathrm{C}\right), 50 \mathrm{mmol}$ tris- $\mathrm{HCl}(\mathrm{pH} 6.0-8.0), 50 \mathrm{mmol}$ glycine ( $\mathrm{pH} 8.0$ to $11.0,24 \mathrm{~h}, 37^{\circ} \mathrm{C}$ ). The assays were performed as above.

\section{RESULTS AND DISCUSSION}

\section{Milk clotting activity}

In this experiment, all the test protein fractions were evaluated for their milk clotting activity. The milk clots obtained show stable consistency over the time period of $40 \mathrm{~min}$ and the exudates are clear and slightly yellow in colour. Milk clotting activity of $\mathrm{L}_{\text {(alb) }}, \mathrm{L}_{\text {(glo) }}, \mathrm{L}_{\text {(pro) }}$ and $\mathrm{L}_{\text {(glu) }}$ was found to be $26.2 \pm 4.7$, $24 \pm 3.9,35.9 \pm 6.2$ units $/ \mathrm{ml}$ and $26.8 \pm 2.5$ respectively at $37^{\circ} \mathrm{C}$ and $\mathrm{pH}$ 6.5. In this present study, $\mathrm{L}_{(\mathrm{alb})}, \mathrm{L}_{\text {(glo), }} \mathrm{L}_{\text {(pro) }}$ and $\mathrm{L}_{\text {(glu) }}$ also registered specific activity of $7,6.1,18.89$ and 5.32 units $/ \mathrm{mg}$ respectively.

The results showed that $\mathrm{L}_{\text {(pro) }}$ has highest milk clotting and specific activity in comparison to other test proteins. As shown in Fig. 5, the skimmed milk coagulations took place based on enzymatic activity of seed proteins. The milk clotting activity of isolated protein of $L$. siceraria was much higher than some plant extracts i.e. in agreement with previously reported article (Mazorra-Manzano et al., 2013) such as S. aculeastrum $(0.56 \pm$ $0.01 \mathrm{U} / \mathrm{ml}), S$. aethiopicum $(2.62 \pm 0.1 \mathrm{U} / \mathrm{ml})$, S. terminale $(1.33 \pm$ $0.02)$. 


\section{Effect of heating, pH on Milk clotting activity}

The effect of temperature and $\mathrm{pH}$ on milk clotting activity was shown in Fig $1 \& 2$. The isolated protein fraction is stable over a wide range of $\mathrm{pH}$ and retained all of its enzymatic activity. The previously incubated protein fractions of $L$. siceraria showed milk clotting activity at $\mathrm{pH} 3$ and loss of activity at $\mathrm{pH}$ values higher than $10 . \mathrm{L}_{(\mathrm{alb})}$ and $\mathrm{L}_{\text {(glo) }}$ showed highest activity at $\mathrm{pH} 5$, but $\mathrm{L}_{(\mathrm{pro})}$ and $\mathrm{L}_{\text {(glu) }}$ exhibited highest activity at $\mathrm{pH} 6$ which is similar to milk clotting activity of culture of Bacillus subtilis (Shieh et al., 2009).

The selection of protease for industrial processes is based on its high thermal stability and wide range of $\mathrm{pH}$. It is well known that the reaction rate of enzymes increases with increasing temperature, but after a certain temperature, the rate of reaction decreases due to denaturation (Hashim et al., 2011).

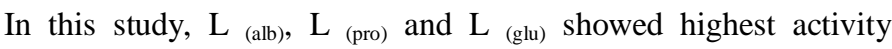
at $40^{\circ} \mathrm{C}$, but the activity decreases with increase in temperature. But $\mathrm{L}_{\text {(glo) }}$ showed highest activity at $60^{\circ} \mathrm{C}$ which is similar to the activity reported by Ahmed et al (Ahmed et al., 2009). It was found that, the milk clotting enzymes present in different fraction of proteins are promising candidates for application in industrial scale for production of cheese. Additionally, use of seed $L$. siceraria in human diet, being eaten raw or cooked is an indicative of safety for use in cheese production.

\section{Proteolytic activity}

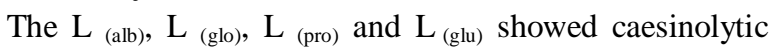
activity $203.4 \pm 0.9,179.64 \pm 1.3,270.17 \pm 2.7,173.71 \pm 0.7$ units/ml and specific activity 54.38, 46.06, 142.19 and 34.53 units/mg respectively (Table-1). From the observed data it was found that $\mathrm{L}_{\text {(pro) }}$ has highest proteolytic and specific activity than the rest protein fractions. The caesinolytic activity of the protein fractions of $L$. siceraria was found more than the isolated proteins obtained from some other plant sources reported earlier (Monica et al., 2008).

\section{Effect of heating, pH on proteolytic activity}

Proteolytic activity of $\mathrm{L}_{\text {(alb) }}$ and $\mathrm{L}_{\text {(glo) }}$ on the substrate, casein significantly enhanced at $\mathrm{pH} 4$ but after $\mathrm{pH} 6$ its activity gradually decreased. The proteolytic activity of $\mathrm{L}_{\text {(pro) }}$ and $\mathrm{L}_{\text {(glu) }}$ was found to be highest at $\mathrm{pH} \mathrm{6,} \mathrm{which} \mathrm{was} \mathrm{similar} \mathrm{to} \mathrm{Euphorbia}$ nivulia (Badgujar et al., 2012) and activity was lowered after pH 7. As shown in Fig. 3, these fractionated proteins were stable under a wide range of $\mathrm{pH}$ (3 to 11 ). $\mathrm{L}_{(\mathrm{alb})}$ and $\mathrm{L}_{(\mathrm{pro})}$ showed optimum activity at $40^{\circ} \mathrm{C}$, which is in agreement with studies reported earlier by Thakur et al (Thakur et al, 1990). Similarly, it was found that $\mathrm{L}_{\text {(glo) }}$ and $\mathrm{L}_{\text {(glu) }}$ exhibited highest activity at $70{ }^{\circ} \mathrm{C}$, which correspond to proteolytic activity of the melon (MazorraManzano et al, 2013).

Table 1: Milk clotting activity and proteolytic activity of protein fractions of L. siceraria.

\begin{tabular}{|c|c|c|c|c|c|}
\hline Protein fractions & $\begin{array}{c}\text { Proteolytic } \\
\text { activity(units/ml) }\end{array}$ & $\begin{array}{c}\text { Milk clotting } \\
\text { activity(units/ml) }\end{array}$ & $\begin{array}{l}\text { Total protein } \\
\text { (mg) }\end{array}$ & $\begin{array}{c}\text { Specific activity for } \\
\text { proteolytic activity } \\
\text { (units/mg) }\end{array}$ & $\begin{array}{c}\text { Specific activity for } \\
\text { MCA } \\
\text { (units/mg) }\end{array}$ \\
\hline Albumin & $203.4 \pm 0.9$ & $26.2 \pm 4.7$ & 3.74 & 54.38 & 7 \\
\hline Globulin & $179.65 \pm 1.3$ & $24.0 \pm 3.9$ & 3.9 & 46.06 & 6.1 \\
\hline Prolamin & $270.17 \pm 2.7$ & $35.9 \pm 6.2$ & 1.9 & 142.19 & 18.89 \\
\hline Glutelin & $173.71 \pm 0.7$ & $26.8 \pm 2.5$ & 5.03 & 34.53 & 5.32 \\
\hline
\end{tabular}

Values are expressed as mean \pm SD
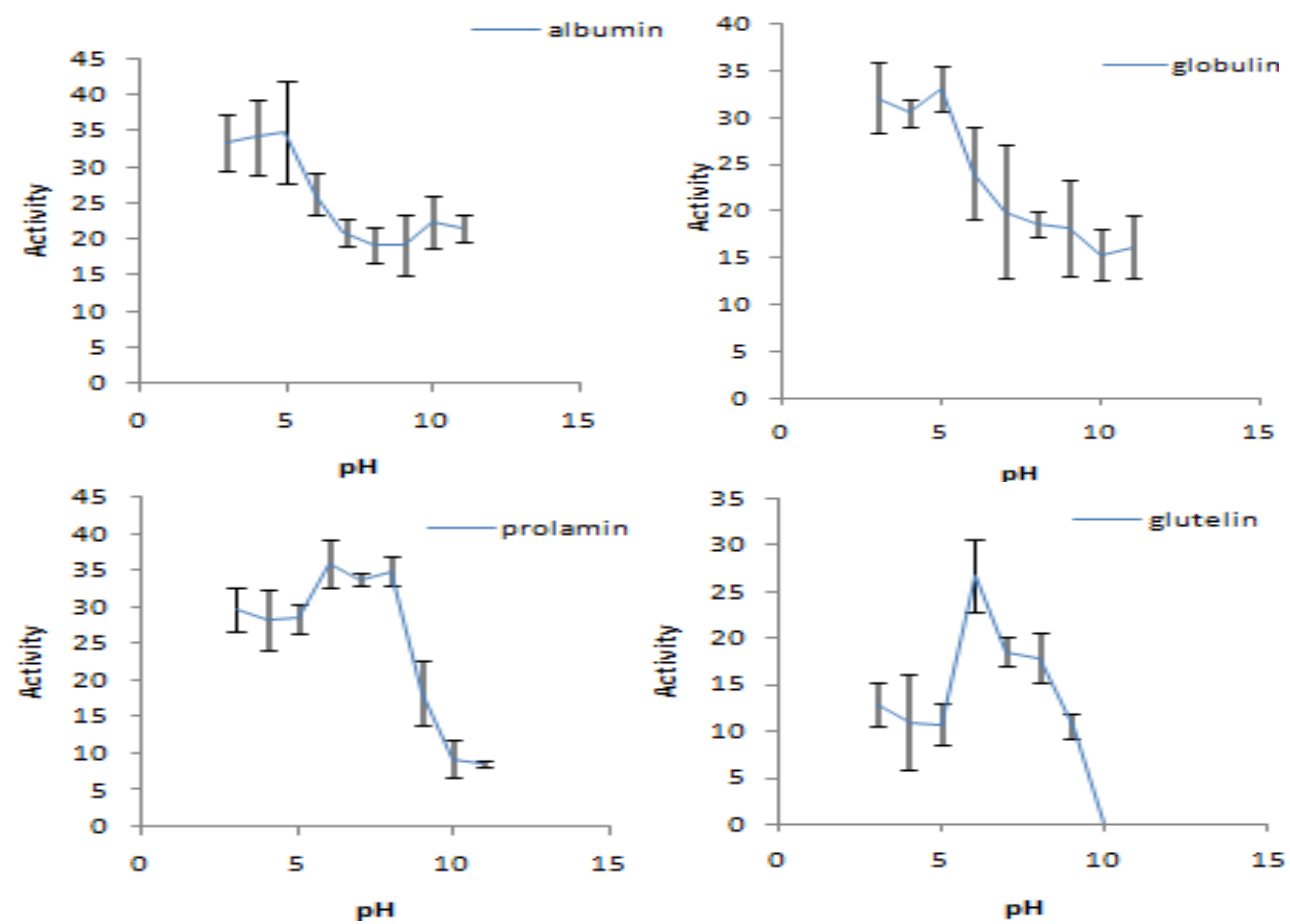

Fig. 1: Milk clotting activity of $L$. siceraria protein fraction of seed at different $\mathrm{pH}$ 

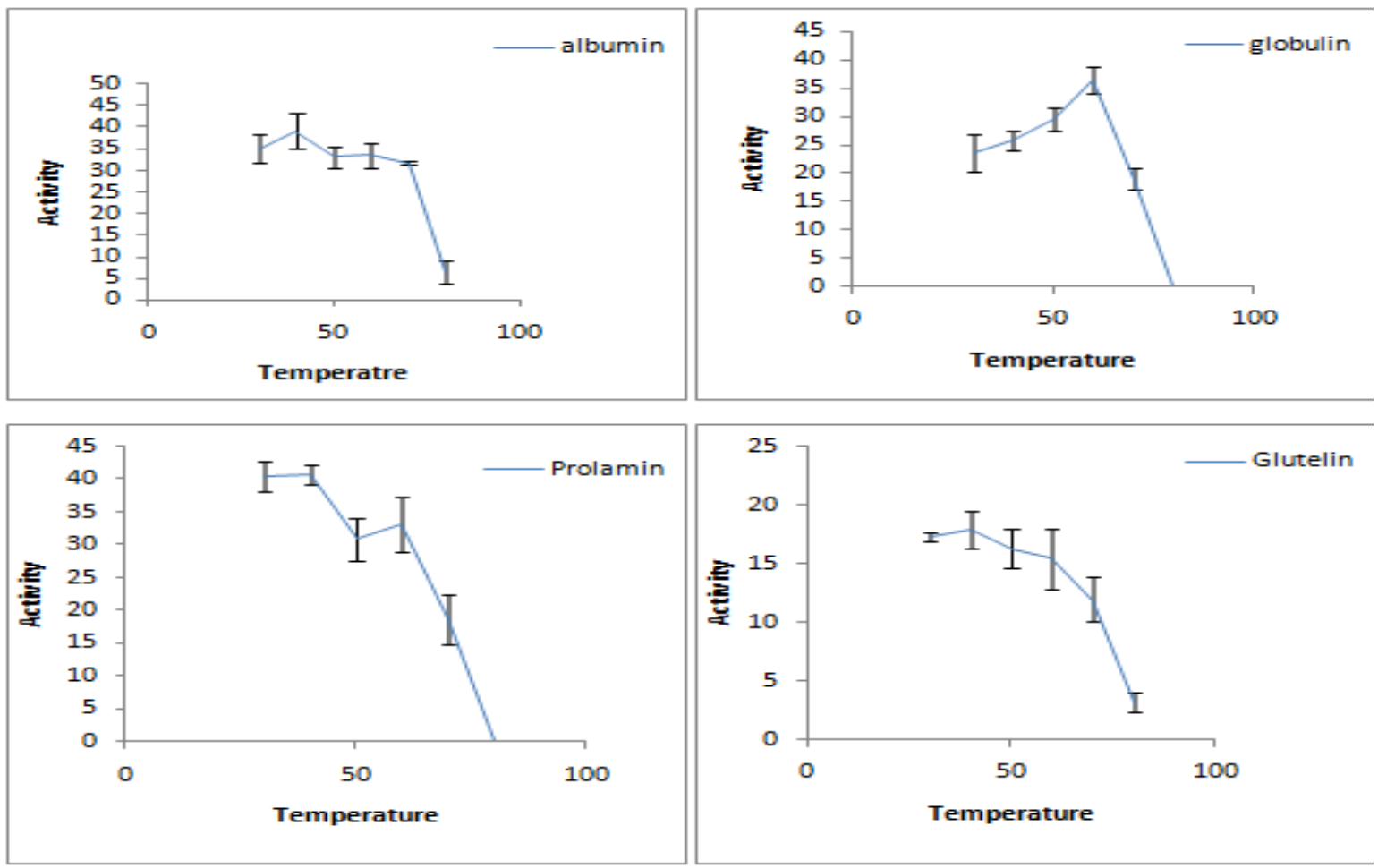

Fig. 2: Milk clotting activity of $L$. siceraria protein fraction of seed at different temperature.
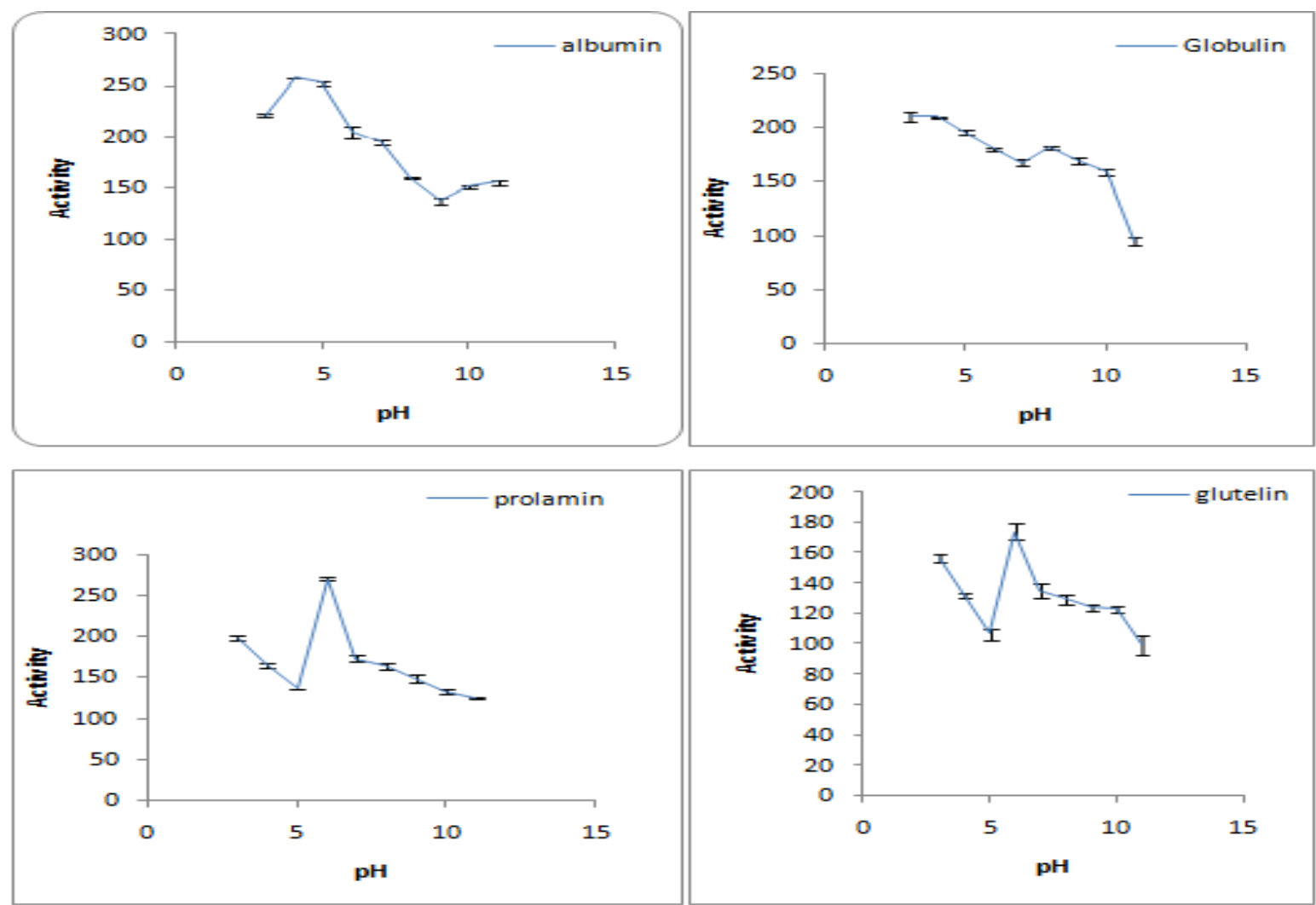

Fig. 3: Proteolytic activity of $L$. siceraria protein fraction of seed at different $\mathrm{pH}$ 

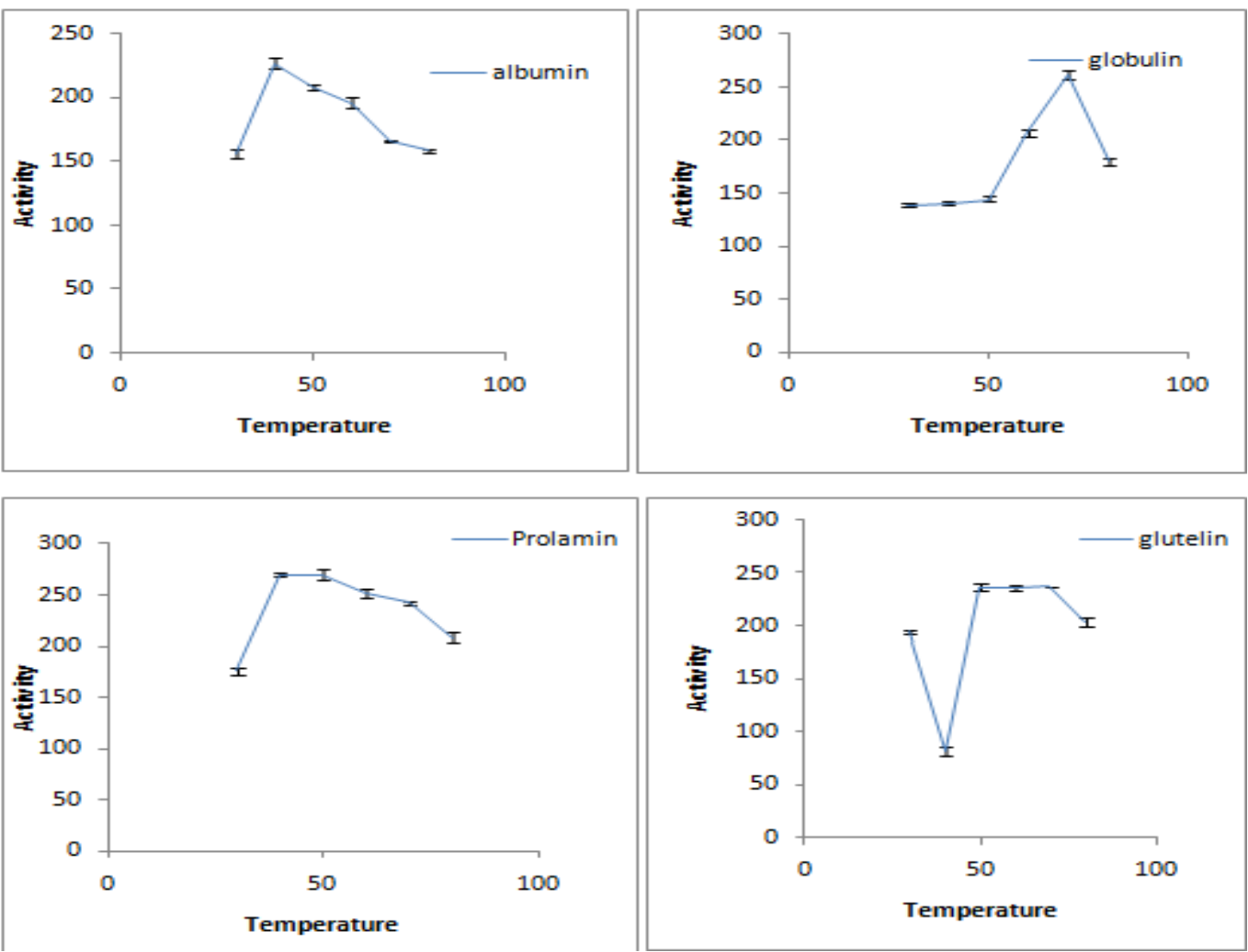

Fig. 4: Proteolytic activity of $L$. siceraria protein fraction of seed at different temperature.

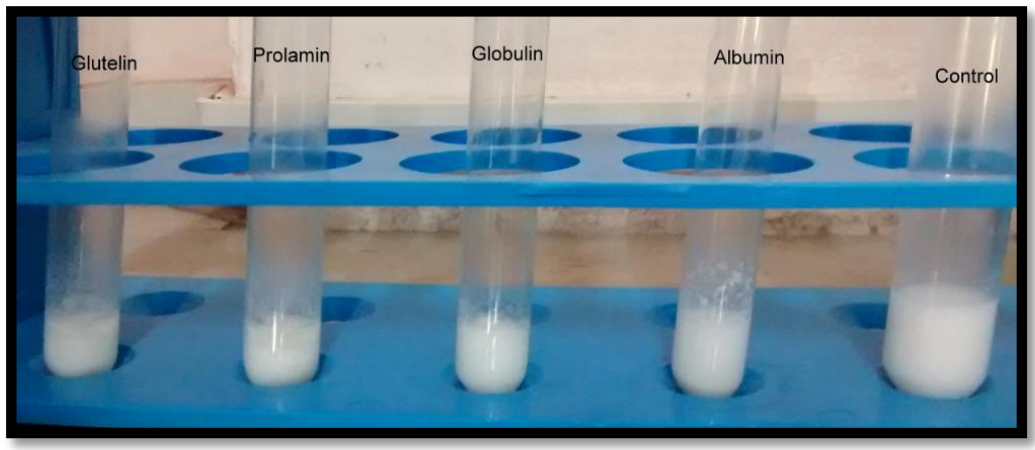

Fig. 5: Milk clotting activity of $L$. siceraria

\section{CONCLUSIONS}

In the present study, it is concluded that among the protein fractions of $L$. siceraria seed, prolamin might be a potentially suitable substitute for commercial animal rennet, being more active than other protein fractions and exhibiting both good milk clotting and caseinolytic activity required for cheeseripening. As many plant rennets generate bitter peptides, experimental cheese-making needs to be carried out with $L$. siceraria to ensure that its seed protein can lead to cheese without bitterness.

\section{REFERNCES}

Ahmed I.A.M., Morishima I., Babiker E.E., Mori N. Characterisation of partially purified milk-clotting enzyme from Solanum dubium Fresen seeds. Food Chem, 2009; 116: 395-400.
Badgujar S.B. and Mahajan R.T. Comparison of cysteine proteases of four laticiferous plants and characterization of Euphorbia nivulia Buch.-Ham. Latex glycosylated cysteine peptidase. Indian J Nat Prod Res, 2012; 3: 152-160.

Bradford M.M. A rapid and sensitive method for the quantitation of microgram quantities of protein utilizing the principle of protein dye binding. Anal Biochem, 1976; 72: 248-254.

Bruno M.A., Lazza C.M., Errasti M.E., Lopez L.M.I, Caffini N.O., Pardo M.F. Milk clotting and proteolytic activity of an enzyme preparation from Bromelia hieronymi fruits. LWT - Food Sci Technol, 2010; 43: 695-701.

Corrons M.A., Bertucci J.I., Liggieri C.S., López L.M.I., Bruno M.A. Milk clotting activity and production of bioactive peptides from whey using Maclura pomifera proteases. LWT - Food Sci Technol, 2012; 47: 103-109.

Gagaoua M., Hoggas N., Hafid K. Three phase partitioning of zingibain, a milk-clotting enzyme from Zingiber officinale Roscoe rhizomes. Int J Biol Macromol, 2015; 73: 245-252.

Hashim M.M., Mingsheng D., Iqbal M.F., Xiaohong C. Ginger rhizome as a potential source of milk coagulating cysteine protease. Phytochem, 2011; 72: 458-464. 
Huang X.W., Chen L.J., Luo Y.B., Guo H.Y., Ren F.Z. Purification, characterization, and milk coagulating properties of ginger proteases. J Dairy Sci, 2011; 94: 2259-2269.

Kumar A., Partap S., Sharma N.K., Jha K.K. Phytochemical, Ethnobotanical and Pharmacological Profile of Lagenaria siceraria: - A Review. J Pharmacog Phytochem, 2012; 1: 24-31.

Mazorra-Manzano M.A., Perea-Gutiérrez T.C., Lugo-Sánchez M.E., Ramirez-Suarez J.C., Torres-Llanez M.J., González-Córdova A.F., Vallejo-Cordoba B. Comparison of the milk-clotting properties of three plant extracts. Food Chem, 2013; 141: 1902-1907.

Meenal S., kubde S.S., Khadabadi I., Farooqui A., Deore S.L. Lagenaria siceraria: Phytochemistry, pharmacognosy and pharmacological studies. Rep Opinion, 2010; 2: 91-98.

Monica G., Parisi M.G., Moreno S., Fernandez G. Isolation and characterization of a dual function protein from Allium sativum bulbs which exhibits proteolytic and hemagglutinating activities. Plant Physiol Biochem, 2008; 46: 403-413.

Ogunbusola E.M., Fagbemi T.N., Osundahunsi O.F. Amino acid composition of Lagenaria sicerari seed flour and protein fractions. J Food Sci Technol, 2010; 47: 656-661.
Ogundele J.O., Oshodi A.A., Sanni T.A., Amoo I. A. Protein isolates of gourd melon seeds and their functional properties. Am J Food Nutr, 2013; 3: 176-181.

Shieh C., Thi L.P., Shih I. Milk-clotting enzymes produced by culture of Bacillus subtilis natto. Biochem Eng J, 2009; 43: 85-91.

Teugwa C.M., Boudjeko T., Tchinda B.T., Mejiato P.C., Zofou D. Anti-hyperglycaemic globulins from selected Cucurbitaceae seeds used as antidiabetic medicinal plants in Africa. BMC Complement Altern Med, 2013; 13: 63.

Thakur M.S., Karanth N.G. Nand K. Production of fungal rennet by Mucor miehei using solid state fermentation. Appl Microbiol Biotechnol, 1990; 32: 409-413.

\section{How to cite this article:}

Dash P, Maharana L, Ghosh G. Proteolytic and Milk Clotting Activity of Fractionated Protein of Lagenaria siceraria. J App Pharm Sci, 2015; 5 (12): 086-091. 